\title{
Quality Perception in Higher Education - Using SERVQUAL Methodology
}

\section{Iara Margolis* and Bernardo Providência}

Lab2PT, University of Minho, Portugal

*Corresponding Author: Iara Margolis, Lab2PT, University of Minho, Portugal.
Received: March 24, 2021

Published: May 17, 2021

(C) All rights are reserved by Iara Margolis and Bernardo Providência.

\begin{abstract}
Understanding the student's perception in higher education goes far beyond student retention. Factors such as satisfaction, motivation and irritability points help not only in a more convergent service planning between the institution's efforts in the face of student expectation, but also in better learning. The perceived quality is difficult to measure and subjective. This work aims to understand the perceived quality of the student and analyze the SERQUAL model for its application in higher education. The 5 dimensions of the model were correlated with academic pillars and the sub-items of each dimension were expanded, according to previous studies. The research was conducted with $15 \%$ of the universe of students from a higher education course, which represents 69 students, from a private institution. The results were validated in a focus group of 5 students using tools such as the Ishikawa diagram and the Interrelationship Diagram. As a result of the application it was diagnosed that students have a higher expectation than the service offered, which results in a perceived negative quality. Points such as 'parking' and 'operational service', which are not essential characteristics of the educational service, directly impact on the perception of quality and consequently on the student's satisfaction. As a main result it was noticed that the method points out the problems that most bother the students. They tend to analyze the whole and camouflage items in the face of these stressful stimuli. The method proved to be an ally in the detection of problems of perceivedfeltquality, but that requires beyond thedetermination of the data to understand the root cause of the results.
\end{abstract}

Keywords: Quality Perception; SERVQUAL; Higher Education; Self-report Methodology; Students Satisfaction

\section{Abbreviation}

QP: Quality Perception.

\section{Introduction}

Higher education education has become a service industry with an attractive, profitable market, with international investments and billion-dollar moves [1,2]. In the Brazilian scenario there is a high dropout rate of students from 2010 to 2019, the cumulative dropout rate is $59 \%$, being $62 \%$ in the private sector [3], this implies numerous losses beyond the financial, such as the emotional difficulties encountered in $83.5 \%$ of students in four years of analysis [4]. Unlike other markets, higher education deals with the conflict of meeting short-term marketing needs and medium/ long-term academic responsibilities [5]. It is also stressed the importance of the student not being able to be seen as a client by educational institutions, since he cannot have the right of the consumer, therefore, not being able to "acquire a diploma" [6].

Thus, the understanding of the expectations and needs of the students becomes a need of the sector, both to retain the student, as for learning. Since the learning process can be enhanced through emotion, motivation, curiosity and challenges or inhibited by anguish, tension, fear or threats [7]. In turn Slater and Narver [8] point out that market orientation is important, but it is not enough to sustain long-term competitive advantages. This corroborates the conflict pointed out earlier and demonstrated by Mark [9] when he states that meeting the demands of students in the short term is 
to lead them to blame the institution for its personal failure, thus requiring caution in decision-making.

Kureemun and Fantina [10] bring the idea of perceived quality, which encompasses subjective factors and perceived value. In a simplified way, the perceived quality is the truth established in the mind of the consumer through the result between expectation and what happened. It transcends tangible metrics, are difficult to measure and of paramount importance, because once understood it translates the perception of the client in the actions of business improvements. For Parasuraman., et al. [11] the perceived quality is the judgment of the consumer about the excellence or general superiority related to a situation, this judgment refers to a different use between consumers and researchers or traders.

An analysis was made in the ten largest private higher education companies in Brazil. It was noticed that the methods of student satisfaction analysis are based on marketing methods, seeing the student as a client. In this case, five of them use the NPS (Net Promoter Score) and four others use the Likert scale in the axes of SINAES in their institutional analysis methods [12]. That is, $90 \%$ of them are based on business metrics without taking into account other factors that directly interfere in the educational sector.

Therefore, we seek alternative methods of self-report that can capture the student's perception in a more holistic and less commercial way within the perceived quality. The work aims to understand the perceived quality of the student and analyze the SERQUAL model for its application in higher education.

The method was applied in July 2019 with 69 production engineering students from one of the largest regional institutions, being the most traditional course in the city and the answers were validated in a focus group with 5 students.

\section{SERVQUAL}

The SERVQUAL model proposed by Parasuraman., et al. [11] it is an instrument developed in five dimensions, from twenty-two items to assess the perception of the client about the quality of service organizations. These items were derived from the ten dimensions of quality of service. In order to evaluate the quality of service, through the perception of the consumer in a quantitative way, it is a multi-item scale based on perceived quality that has good reliability and validity, aiming at improving the service. This methodology measures two statements: (1) expectation and (2) perception of service consumption and can be used with employees, cur- rent or past customers. The analysis takes place on a seven-point scale, starting from 'totally disagree' to 'strongly agree'.

The factors that interfere in the perception of the student are not convergent between the authors. For this reason, table 1 [13] presents a demonstration of divergence between authors regarding the metrics that influence the perceived experience in view of the satisfaction of the student of the educational service.

\begin{tabular}{|c|c|c|}
\hline Column & Authors & $\begin{array}{c}\text { Factors that influence student } \\
\text { satisfaction }\end{array}$ \\
\hline 1 & $\begin{array}{c}\text { Thomas e } \\
\text { Galambos } \\
{[14]}\end{array}$ & $\begin{array}{c}\text { (1) academic experiences, (2) social } \\
\text { integration and pre-registration } \\
\text { opinions and (3) campus services and } \\
\text { facilities }\end{array}$ \\
\hline 2 & $\begin{array}{l}\text { Peng and } \\
\text { Samah [15] }\end{array}$ & $\begin{array}{l}\text { (1) Course content (suitability of cou- } \\
\text { rse requirements, skills development, } \\
\text { career preparation, course material } \\
\text { quality, program usefulness and perso- } \\
\text { nal needs); (2) Teacher and Institution } \\
\text { (availability of assistance offered by the } \\
\text { out-of-class HEI, the organization of } \\
\text { classes, the disposition of teachers out- } \\
\text { side class hours, the personal attention } \\
\text { that students receive); (3) The evalua- } \\
\text { tion of the course (the chances of the } \\
\text { student succeeding if it is dedicated to } \\
\text { the adequacy of the contents offered); } \\
\text { (4) The means of instruction (lectures } \\
\text { and tasks in the compatible langua- } \\
\text { ge); (5) Social activities; (6) Concerns } \\
\text { with students (availability of people } \\
\text { to whom students can ask for help); } \\
\text { (7) Physical facilities (includes library, } \\
\text { leisure environments for students to } \\
\text { relax throughout the day, laboratories, } \\
\text { availability of computing resources, } \\
\text { recreational facilities, availability of } \\
\text { classroom activities). }\end{array}$ \\
\hline 3 & Gibson [16]. & $\begin{array}{l}\text { (1) quality of teaching, (2) quality of } \\
\text { the curriculum, (3) skills and knowl- } \\
\text { edge acquired and (4) achievement of } \\
\text { learning objectives (5) availability, (6) } \\
\text { quality of facilities and services (7) } \\
\text { capacity and response of the academic } \\
\text { and support staff (8) feeling of "belong- } \\
\text { ing", or degree of social integration, } \\
\text { (9) perceptions of the institution's } \\
\text { responsiveness and (10) concern of the } \\
\text { institution }\end{array}$ \\
\hline
\end{tabular}




\begin{tabular}{|c|c|c|}
\hline 4 & $\begin{array}{c}\text { Parasura- } \\
\text { man., et al. } \\
{[11,17] \text { - }} \\
\text { SERVQUAL }\end{array}$ & $\begin{array}{l}\text { (1) tangibility, (2) reliability, (3) re- } \\
\text { sponsiveness, (4) communication, (5) } \\
\text { credibility, (6) security, (7) compe- } \\
\text { tence, (8) courtesy, (9) understanding/ } \\
\text { knowledge of the customer and (10) } \\
\text { access. }\end{array}$ \\
\hline 5 & $\begin{array}{l}\text { LeBlanc and } \\
\text { Nguyen [18] } \\
\text { - Based on } \\
\text { SERVQUAL }\end{array}$ & $\begin{array}{l}\text { (1) Curriculum (course content, pro- } \\
\text { gram orientation, number of courses } \\
\text { offered, degree that program objectives } \\
\text { are explained to students); (2) Physical } \\
\text { evidence (layout and lighting of the } \\
\text { classroom, general physical appea- } \\
\text { rance, cleanliness, degree of comfort, } \\
\text { decoration and environmental “atmos- } \\
\text { phere"); (3) Ability to answer (time of } \\
\text { availability of information to students, } \\
\text { assertiveness and accuracy of records); } \\
\text { (4) Access to facilities (parking, access } \\
\text { to computers, access to classrooms and } \\
\text { study rooms); (5) Reputation (if the } \\
\text { HEI is innovative, its organizational cul- } \\
\text { ture, beliefs, values, the institution's in- } \\
\text { volvement with the community, degree } \\
\text { of curriculum updating, administrative } \\
\text { actions being aligned with students); } \\
\text { (6) Management (administration and } \\
\text { availability of people, friendliness and } \\
\text { cordiality, ability to solve problems } \\
\text { when they arise, knowledge of the rules } \\
\text { and procedures by employees); (7) } \\
\text { Teachers' aptitude (teacher aptitu- } \\
\text { de and appearance, friendliness and } \\
\text { cordiality of faculty, research produc- } \\
\text { tivity; communication skills, teachers' } \\
\text { academic credentials, whether teachers } \\
\text { are innovators and change managers). }\end{array}$ \\
\hline 6 & $\begin{array}{l}\text { Douglas., } \\
\text { et al. [19] } \\
\text { - Based on } \\
\text { SERVQUAL }\end{array}$ & $\begin{array}{l}\text { (1) care, (2), teacher training, (3) tea- } \\
\text { ching methods, (4) attitude, (5) content } \\
\text { and (6) infrastructure. }\end{array}$ \\
\hline
\end{tabular}

Table 1: Factors surveyed that influence student satisfaction. Source: adapted from Ribeiro., et al. [13].

Gibson [16] shows that non-academic factors (items 8, 9 and 10 in column 3) are often the cause of students' dissatisfaction in the overall academic experience, that academic items 1, 2, 3 and 4 are the most significant and determinant for overall satisfaction, and also states that the influence variables vary according to the institution and the student.

The SERVQUAL methodology was suggested by Parasuraman., et al. $[11,17]$. Initially, 10 items of analysis were presented and later perceived overlap between them. Therefore, the model was reduced to 5 items - concatenating in its last two dimensions seven items of the original dimensions of the service (communication, credibility, security, competence, courtesy, understanding /knowledge of customers and access). The five proposed dimensions are [11]:

- Tangibility: Physical facilities, equipment and the appearance of employees;

- Reliability: The ability to perform the promised service reliably and accurately;

- $\quad$ Responsiveness (responsiveness): Willingness to help customers and provide the service;

- Warranty: Knowledge and courtesy of employees and their ability to inspire confidence;

- Empathy: The service, the individualized attention that the company offers to the client.

According to Bearden, Netemeyer and Haws [20], the tool is composed of the equalization of two answers related to the expectation and reality of a specific service. It is an analysis of 22 items, which uses the Likert scale of 7 points, the 7 (seven) which "strongly agree", to 1 (one), "strongly disagree" in the subscales of analysis: (1) tangibility, (2) reliability, (3) responsiveness, (4) assurance and (5) empathy.

Lourenço and Knop [21] conducted the SERVQUAL research in Portuguese in the academic sector, using Cronbach's Alpha to measure the reliability of the tool. They used the five dimensions, divided into 22 items of analysis, as shown in table 2 .

\begin{tabular}{|c|c|c|}
\hline Dimension & Description of Variables & $\begin{array}{l}\text { Variable } \\
\text { Name }\end{array}$ \\
\hline \multirow[t]{6}{*}{$\begin{array}{l}\text { Tangibili- } \\
\text { dade }\end{array}$} & $\begin{array}{l}01 \text { - Suitable physical facilities (com- } \\
\text { fortable, airy, illuminated) }\end{array}$ & $\begin{array}{l}\text { Physical } \\
\text { Facilities }\end{array}$ \\
\hline & $\begin{array}{l}02 \text { - Has library with adequate } \\
\text { collection }\end{array}$ & Library \\
\hline & $\begin{array}{c}03 \text { - Has adequate computer labora- } \\
\text { tory (quantity and characteristics of } \\
\text { the equipment) }\end{array}$ & $\begin{array}{l}\text { Computer } \\
\text { Lab }\end{array}$ \\
\hline & $\begin{array}{l}04 \text { - Has adequate technological } \\
\text { resources (projector, computer...) }\end{array}$ & $\begin{array}{l}\text { Technologi- } \\
\text { cal Resour- } \\
\text { ces }\end{array}$ \\
\hline & $\begin{array}{l}05 \text { - Has good-looking staff and tea- } \\
\text { chers (well dressed, organized) }\end{array}$ & $\begin{array}{c}\text { Good } \\
\text { Looking }\end{array}$ \\
\hline & $\begin{array}{l}06 \text { - Teachers use teaching materials } \\
\text { of good presentation }\end{array}$ & $\begin{array}{l}\text { Teaching } \\
\text { materials }\end{array}$ \\
\hline
\end{tabular}




\begin{tabular}{|c|c|c|}
\hline \multirow[t]{6}{*}{ Reliability } & $\begin{array}{c}07 \text { - The course promoted academic } \\
\text { or executive lectures }\end{array}$ & Lectures \\
\hline & $\begin{array}{c}08 \text { - The course carried out technical } \\
\text { visits }\end{array}$ & $\begin{array}{l}\text { Technical } \\
\text { Visits }\end{array}$ \\
\hline & $\begin{array}{c}09 \text { - The course promoted extension } \\
\text { courses }\end{array}$ & $\begin{array}{l}\text { Extension } \\
\text { Courses }\end{array}$ \\
\hline & $\begin{array}{l}10 \text { - Disciplines are relevant for pro- } \\
\text { fessional training }\end{array}$ & $\begin{array}{c}\text { Professional } \\
\text { Training }\end{array}$ \\
\hline & $\begin{array}{l}11 \text { - Teachers balance theory and } \\
\text { practice in the classroom }\end{array}$ & $\begin{array}{l}\text { Theory and } \\
\text { practice }\end{array}$ \\
\hline & $\begin{array}{l}12 \text { - Teachers have the ability to } \\
\text { arouse the student's interest in the } \\
\text { contents }\end{array}$ & $\begin{array}{l}\text { Create Inte- } \\
\text { rest }\end{array}$ \\
\hline \multirow[t]{2}{*}{ Alacrity } & $\begin{array}{l}13 \text { - The service provided by the staff } \\
\text { of the secretariat is adequate }\end{array}$ & $\begin{array}{l}\text { Attendance } \\
\text { of the secre- } \\
\text { tariat }\end{array}$ \\
\hline & $\begin{array}{l}14 \text { - Teachers show sincere interest } \\
\text { in helping students }\end{array}$ & $\begin{array}{l}\text { Interest in } \\
\text { helping }\end{array}$ \\
\hline \multirow[t]{6}{*}{ Security } & $\begin{array}{l}15 \text { - Provides communication ele- } \\
\text { ments (murals, manuals, warnings, } \\
\text { emails) that keep students informed }\end{array}$ & $\begin{array}{l}\text { Communica- } \\
\text { tion }\end{array}$ \\
\hline & $\begin{array}{l}16 \text { - Teachers are able to provide } \\
\text { satisfactory answers to students' } \\
\text { questions }\end{array}$ & $\begin{array}{l}\text { Correct } \\
\text { answers }\end{array}$ \\
\hline & $\begin{array}{l}17 \text { - Teachers have mastery of the } \\
\text { subjects dealt with }\end{array}$ & $\begin{array}{l}\text { Mastery of } \\
\text { affairs }\end{array}$ \\
\hline & 18 - Teachers inspire confidence & Trust \\
\hline & $\begin{array}{l}19 \text { - Teachers are fair in student } \\
\text { performance assessments }\end{array}$ & $\begin{array}{c}\text { Justice in } \\
\text { evaluations }\end{array}$ \\
\hline & $\begin{array}{l}20 \text { - Teachers and staff are always } \\
\text { courteous with students }\end{array}$ & Courtesy \\
\hline \multirow[t]{2}{*}{ Empathy } & $\begin{array}{l}21 \text { - The school understands the } \\
\text { specific needs of students }\end{array}$ & $\begin{array}{l}\text { Specific } \\
\text { needs }\end{array}$ \\
\hline & $\begin{array}{l}22 \text { - Teachers give individualized } \\
\text { attention to students }\end{array}$ & $\begin{array}{l}\text { Individuali- } \\
\text { zed atten- } \\
\text { tion }\end{array}$ \\
\hline
\end{tabular}

Table 2: SERVQUAL questions for the academic sector.

Source: adapted from Lourenço and Knop [21].

The calculation is made with the average of the perceived quality subtracted by the expected quality average, the difference is the gap and must be made for each item. Its reliability validation can be analyzed by cronbach's alpha consistency, which should be at least more than 0.7 [22]. If the difference is positive, it means that what is perceived is higher than expected. What is important to note is that if you reverse the subtraction, the analysis is reversed.

Cabello and Chirinos [23] corroborate the good reliability when Cronbach's alpha is greater than 0.7 and the calculation is the difference between perception and expectation, with the positive value being related to satisfaction and negative value to dissatisfaction, and can make the calculation for each dimension or each question item.

The SERVQUAL model has been used in several studies in the educational sector and showing some secondary divergences in the priorities of the results, but as main the variation between academic and teaching factors [19,24-27]. Sohail and Shaikh [28] reduced to six variables, which brought together in a single the management and aptitude items of teachers. Douglas., et al. [19] they used 6 categories in 19 SERVQUAL attributes. Hasan., et al. [24] highlight empathy as the strongest factor, followed by assurance, tangibility, responsiveness, and reliability. Douglas., et al. [19] showed that the most important factors in perceived quality are related to academic service, while physical aspects do not interfere so much in student satisfaction, but influence the choice of the study site. The authors suggest the alignment of information, such as service standards and deadlines, to have a "quality standard". In the Brazilian scenario, it was noticed that the attributes vary according to the higher education institution. In private institutions appeared the conflict between teaching, human resources and infrastructure, having many additional attributes when compared with public institutions.

Lourenço and Knop [21] also analyze in five dimensions, but change the "Responsiveness" by "Presteza" and "Guarantee" by "Security". In general, the changes are more nominal. In the first, the main idea is the service focused on the employee's disposition and the second on the service provided, focused on communication and parameters for the client. Another divergence between the authors is that in the reliability Lourenço and Knop [21] add the academic part, such as lectures, extension courses, technical visits, professional training, the correlation of theory with practice and even the creation of interest for the student.

There are also studies with variation in the number of topics, using 38 items of analysis instead of 22, as shown in table 2. This study suggested the strong relationship between Perceived Quality and the reputation of a higher education institution, both in strategic alignment and in the alignment of teacher behavior [18].

Despite the recognition for being a valuable methodology for periodic use, easy to apply, with flexibility and for the analysis of service trend, SERVQUAL was criticized by some authors [19,29$31]$, the reasons or questions were:

- Do not have data associated with expectations;

- Not be a model applied to all types of service, such as for industrial services; 
- Whether the five elements are independent and sufficient.

- If the evaluators' perspective is aligned with the research premises.

Another counterpoint to the methodology is highlighted by Galloway [32] who states that it does not adapt well to the situation and that it does not contribute to the analysis of perceived value, especially when addressing a part of the organization. The method was applied with students and employees of an HEI and one of its conclusions was that one of the variables is the degree of use of the service through the clients, because the superficiality and judgment of the service are related to the degree of knowledge of these and their interests. The case becomes more particular since these 'clients' have ties to the services, so they seek to "take advantage" of this longer-lasting relationship, as well as their interests change over time this perception.

Finally, Kureemun and Fantina [10] agree that there are several ways to learn about the perspectives of customers, but stress that no method is sufficient, since the perception of quality is difficult to evaluate and very difficult to measure. Research is one of the ways to gather the facts, but they will not offer all the necessary information. They alone are not enough, they have a low rate of support and the questions do not get to the heart of the problem. However, they provide some indicators of what respondents think. Questions should be "raw" and data analysis should see "raw", this means analyzing all the information added to the optional survey comments. This field is what the customer is really thinking. Thus, they suggest some complementary techniques for data analysis, i.e.:

- Categorization: Similar data will converge and should be categorized together;

- Prioritize: Once problems are categorized, they should be prioritized. The suggestion in this step is the interrelationship diagram of the six sigmas methodology;

- Root cause analysis: Investigating the root cause of the problem is of paramount importance, several methods can be used, and the suggested methods are: cause and effect diagram and the methodology of the five whys.

This is the only way to validate the data. The Kureemun and Fantina model was the only schematized model found with efficient results and using concrete tools. For the treatment of data, the authors also highlight some tools [10].
- Cause and effect diagram, Ishikawa or fishbone: Aims to establish the relationship of causes with effects, in which for each effect has several categories of causes that may have subcategories [33] once the analyzed "problem" has been determined, this diagram allows to analyze in a systemic way the cause-effect relationship. The causes that probably generate the effects are written and each of them is investigated further, in a playful format (similar to a fishbone) [34];

- Five reasons: It is a simple technique of questioning with great effectiveness, assists in mapping processes or in the search for problems or causes [33]. For each cause, one wonders why it. The answer, again, is questioned why. And so, successively, five times, until it reaches the root cause;

- Interrelationship diagram: Kureemun and Fantina [10] suggest the following steps for the interrelationship diagram: (1) Each category enters a card, divided into three parts (2) inviting key stakeholders to a meeting; (3) the cards should be in a large circle; (4) guests are asked if each category is influenced by the other. If the answer is positive, it is necessary to find out what the influence is. It is important to highlight that there should be a consensus among the members regarding influence and which is the most influential; (5) participants have to draw an arrow coming out of those who influence and reaching the influenced; (6) at the end, it is necessary to count the number of arrows that enter each category and the number that leaves. Incoming numbers should be noted in the lower left and output numbers in the lower right corner, as shown in figure 1.

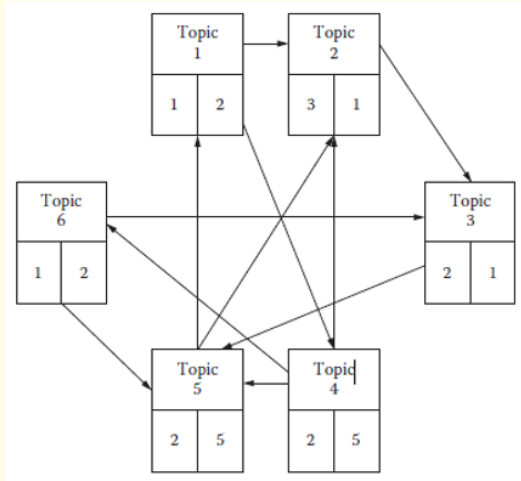

Figure 1: Interrelationship Diagram. Source: Kureemun and Fantina [10]. 
The topics with the highest number of departures are the "drivers" and the input topics are the "results"; with this, one should determine the area that needs immediate attention.

\section{Materials and Methods}

The SERVQUAL method has already been applied to measure satisfaction in the academic universe [19,24-27]. In general following the 5 pillars (tangibility, reliability, responsiveness, assurance and empathy) for quality of service analysis proposed by the authors Parasuraman., et al. [11,17] and also validated and referenced by Swartz and Brown [36]. However, it was possible to see divergence in several items, such as the number of dimensions $[19,28]$ and in the number of items analyzed $[19,31]$, in addition to the structure of the research itself [21,24]. This highlights a special emphasis on Galloway's criticism [32] when it comes to not adapting well to situations, especially when analyzing parts of the organization.

Given this non-unanimity already presented, it was decided to apply the SERVQUAL model in higher education, in students of the Production Engineering Course. The choice of the course was made in view of the tradition of the course in the region, the knowledge of the researcher with the weaknesses, strengths, threats and opportunities of the course, as well as the criticality of the selection of students for the focus group.

The main objective is to analyze the tool and the items that must be analyzed within the dimensions. It comes out from the premise that regardless of the methodological divergence found, the understanding of the perception of quality under an aspect already validated in the educational area, could help in the analysis of the present study. In view of Galloway's analysis [32] it was then decidedto apply SERVQUAL with all dimensions analyzed in previous studies where 44 students from different academic areas and moments were interviewed to better understand the sectors that interfere in the student's satisfaction [13]. Soon the items were based on Table 2 , together with the guidelines of Parasuraman., et al. $[11,17]$ and with figure 2 .

Table 3 presents the final result, which contains 70 items of analysis, categorized in the 5 pillars proposed in figure 1 and added the '-' when there was no convergence
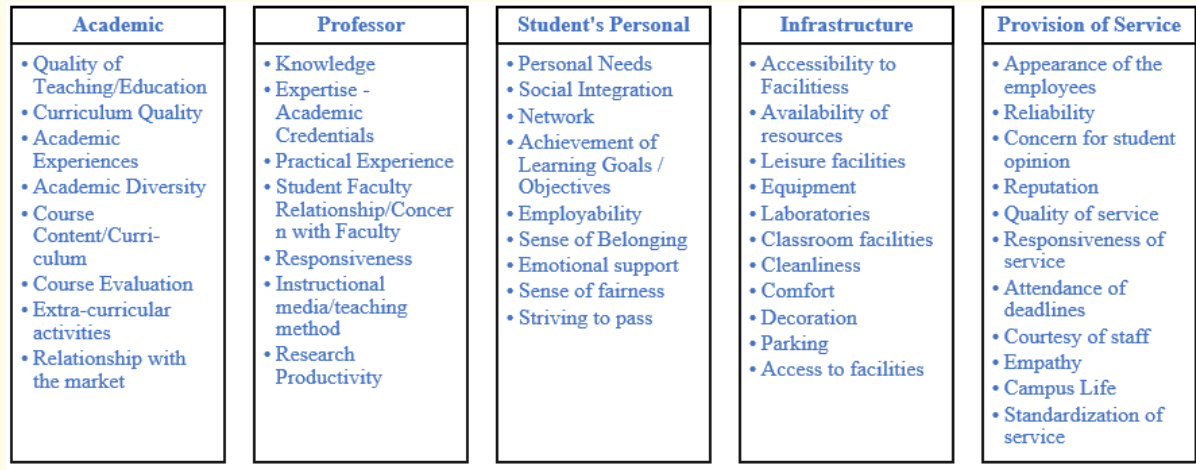

Figure 2: Pillars for analysis of perception and satisfaction of the student. Fonte: Ribeiro., et al. [13].

\begin{tabular}{|c|c|c|}
\hline $\mathbf{N}$ & Questions asked & $\begin{array}{c}\text { Items from an } \\
\text { HEI }\end{array}$ \\
\hline 01 & $\begin{array}{c}\text { Physical facilities are visually appealing/ } \\
\text { beautiful }\end{array}$ & Infrastructure \\
\hline 02 & General campus facilities be comfortable & Infrastructure \\
\hline 03 & Campus security & - \\
\hline 04 & $\begin{array}{c}\text { The appearance of the HEI to be consis- } \\
\text { tent with what it promises to be }\end{array}$ & Infrastructure \\
\hline 05 & Laboratory equipment is modern & Infrastructure \\
\hline
\end{tabular}

\begin{tabular}{|c|c|c|}
\hline 06 & The library have updated books & Infrastructure \\
\hline 07 & The library have enough books & Infrastructure \\
\hline 08 & The library have diversity & Infrastructure \\
\hline 09 & Employees are well dressed/tidy & Service \\
\hline 10 & $\begin{array}{c}\text { The classrooms are comfortable and at- } \\
\text { tractive }\end{array}$ & Infrastructure \\
\hline 11 & $\begin{array}{c}\text { Lesson equipment is modern and efficient } \\
\text { ule }\end{array}$ & Infrastructure \\
\hline 12 & $\begin{array}{c}\text { The Institution meet the promised sched- } \\
\text { Academic }\end{array}$ \\
\hline
\end{tabular}




\begin{tabular}{|c|c|c|}
\hline 13 & $\begin{array}{l}\text { Teachers meet the pre-established sched- } \\
\text { ule for classes }\end{array}$ & Teacher \\
\hline 14 & $\begin{array}{l}\text { THE IES have an interest in solving stu- } \\
\text { dent problems }\end{array}$ & Service \\
\hline 15 & There is quality in teaching & Academic \\
\hline 16 & $\begin{array}{l}\text { Academic experiences aggregate the } \\
\text { course }\end{array}$ & Academic \\
\hline 17 & The content of the updated disciplines & Academic \\
\hline 18 & The teachers' curriculum is good & Teacher \\
\hline 19 & Teachers have knowledge & Teacher \\
\hline 20 & $\begin{array}{c}\text { Teachers have practical mastery of knowl- } \\
\text { edge }\end{array}$ & Teacher \\
\hline 21 & $\begin{array}{c}\text { Teachers have productivity of academic } \\
\text { research }\end{array}$ & Teacher \\
\hline 22 & Teacher's concern for the student & Teacher \\
\hline 23 & Quickly meet student demands & Service \\
\hline 24 & $\begin{array}{l}\text { Meet the deadlines set in the academic } \\
\text { part }\end{array}$ & Academic \\
\hline 25 & $\begin{array}{l}\text { Meet the deadlines set in the administra- } \\
\text { tive part }\end{array}$ & Service \\
\hline 26 & Employees are always willing to help & Service \\
\hline 27 & $\begin{array}{l}\text { Employees to accurately inform the date } \\
\text { of service delivery }\end{array}$ & Service \\
\hline 28 & $\begin{array}{l}\text { Employees have Responsiveness (ability } \\
\text { to respond or indicate where to find the } \\
\text { answer) }\end{array}$ & Service \\
\hline 29 & $\begin{array}{c}\text { Employees are always too busy to serve } \\
\text { the customer }\end{array}$ & Service \\
\hline 30 & Teachers be trusted & Teacher \\
\hline 31 & Employees be trusted & Service \\
\hline 32 & $\begin{array}{l}\text { Employees fully understand the student's } \\
\text { needs/feelings }\end{array}$ & Service \\
\hline 33 & $\begin{array}{l}\text { Teachers fully understand the student's } \\
\text { needs/feelings }\end{array}$ & Teacher \\
\hline 34 & $\begin{array}{l}\text { The HEI give individualized attention to } \\
\text { each student }\end{array}$ & Service \\
\hline 35 & $\begin{array}{l}\text { Teachers give individualized attention to } \\
\text { each student }\end{array}$ & Teacher \\
\hline 36 & IES' reputation in the labour market & Service \\
\hline 37 & $\begin{array}{l}\text { Feel safe (in the emotional sense and not } \\
\text { safety-danger) with employees }\end{array}$ & - \\
\hline 38 & Employees be polite/kind & Service \\
\hline 39 & Teachers be polite/kind & Teacher \\
\hline 40 & Teachers know how to answer questions & Teacher \\
\hline
\end{tabular}

\begin{tabular}{|c|c|c|}
\hline 41 & $\begin{array}{c}\text { Employees know how to answer ques- } \\
\text { tions }\end{array}$ & Service \\
\hline 42 & $\begin{array}{l}\text { Teachers embark together in the interests } \\
\text { of students }\end{array}$ & Teacher \\
\hline 43 & $\begin{array}{l}\text { Employees fully understand customer } \\
\text { needs/feelings }\end{array}$ & Service \\
\hline 44 & Class schedules are at convenient times & Academic \\
\hline 45 & $\begin{array}{l}\text { THE IES is concerned about the student's } \\
\text { opinion }\end{array}$ & Service \\
\hline 46 & Provides an extra classroom campus life & Service \\
\hline 47 & Service standardization & Service \\
\hline 48 & They have social activities & - \\
\hline 49 & Has network with students & $\begin{array}{l}\text { Student's } \\
\text { Personal }\end{array}$ \\
\hline 50 & Has network with teachers & Teacher \\
\hline 51 & $\begin{array}{l}\text { There is monitoring of the employability } \\
\text { needs of students }\end{array}$ & $\begin{array}{l}\text { Student's } \\
\text { Personal }\end{array}$ \\
\hline 52 & $\begin{array}{l}\text { There is the accompaniment of the feeling } \\
\text { of belonging }\end{array}$ & $\begin{array}{l}\text { Student's } \\
\text { Personal }\end{array}$ \\
\hline 53 & The emotional support given by IES & $\begin{array}{l}\text { Student's } \\
\text { Personal }\end{array}$ \\
\hline 54 & $\begin{array}{c}\text { There's a sense of justice inside the } \\
\text { classroom }\end{array}$ & $\begin{array}{l}\text { Student's } \\
\text { Personal }\end{array}$ \\
\hline 55 & $\begin{array}{l}\text { The effort that the student makes to pass } \\
\text { in the disciplines }\end{array}$ & $\begin{array}{l}\text { Student's } \\
\text { Personal }\end{array}$ \\
\hline 56 & The level of evaluation & - \\
\hline 57 & The teacher's methodology is playful & Teacher \\
\hline 58 & The constant extracurricular activities & Academic \\
\hline 59 & Academic diversity & Academic \\
\hline 60 & Students' commitment to study & $\begin{array}{l}\text { Student's } \\
\text { Personal }\end{array}$ \\
\hline 61 & $\begin{array}{l}\text { There are scholarships and funding for } \\
\text { students }\end{array}$ & Service \\
\hline 62 & Evaluation of the course in mec & Academic \\
\hline 63 & Evaluation of THE HEI in mec & Academic \\
\hline 64 & Environment for social integration & $\begin{array}{l}\text { Student's } \\
\text { Personal }\end{array}$ \\
\hline 65 & It has clean environment & Infrastructure \\
\hline 66 & It has comfortable environment & Infrastructure \\
\hline 67 & It has decorated environment & Infrastructure \\
\hline 68 & It has Parking & Infrastructure \\
\hline 69 & It has leisure facilities & Infrastructure \\
\hline 70 & Service standardization & Service \\
\hline
\end{tabular}

Table 3: EXPANDED SERVQUAL - points used in the experiment. 
It is possible to notice that there are similar items, such as 33 and 43 , however, one highlights the student's bias and the client's other, according to the paradigm initially addressed in relation to the commercial view and educational vision.

It is necessary to observe a possible limitation of this technique. When the questionnaire is too large, the interviewees tend to present a predisposition to maintain the same answer [36,37]. It is understood, therefore, that Cronbach's alpha should result in a high humerus of redundant items.

Regarding the dimensions of SERVQUAL, the 5 dimensions of the authors Parasuraman., et al. [11,17] and Lourenço and Knop [21] as follows:

- Tangibility: Focused on everything that can be tangible (physical facilities, technological resources, appearance of employees and environment);

- $\quad$ Reliability: Deliver what was promised, schedule, reliability of the teacher and what the course is pre-disposed to have in the academic part;

- Promptness in the service: Encompassing the responsiveness, service and willingness of employees to the service;

- Intangibility: Focused on the intangible part, has as items belonging to the knowledge and courtesy of employees, the communication of the HEI and the feeling of justice, group, security and trust;

- Empathy: Individualized care, attention to students' feelings towards the HEI.

Table 4 shows the correlation of the data from this perspective, where there is a correlation between "Tangibility" and "Infrastructure"; "Reliability" and "Academic", but with a strong participation of "Teachers"; "Promptness of service" and "Provision of Service"; and "Intangibility" with "Student Personnel". In the dimension "Empathy" there is a mixture of 'service', 'teachers' and 'customer needs'.

In addition to these changes, at the end of the questionnaire there was an open space where they questioned what the partici-

\begin{tabular}{|c|c|c|}
\hline Dimension & Question number & $\begin{array}{l}\text { Predominance of } \\
\text { the Item of the HEI }\end{array}$ \\
\hline $\begin{array}{l}\text { Tangibili- } \\
\text { dade }\end{array}$ & $\begin{array}{c}\text { Infrastructure: } 01,02 \text {, } \\
04,05,06,07,08,10,11 \text {, } \\
65,66,67,68,69 \\
\text { Service: } 09\end{array}$ & Infrastructure \\
\hline Reliability & 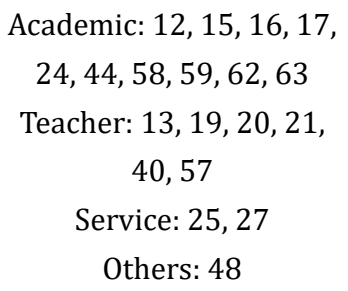 & $\begin{array}{l}\text { 1st Place: Academic } \\
\text { 2nd Place: Teacher }\end{array}$ \\
\hline $\begin{array}{c}\text { Promptness } \\
\text { in service }\end{array}$ & $\begin{array}{c}\text { Teacher: } 39 \\
\text { Service: } 14,23,26,28, \\
29,38,41,46,47,61,70\end{array}$ & Provision of Service \\
\hline $\begin{array}{l}\text { Intangibi- } \\
\text { lity }\end{array}$ & $\begin{array}{c}\text { Teacher: } 18,30,50 \\
\text { Student Personnel: } 49 \text {, } \\
\text { 54, 55, 60, } 64 \\
\text { Service: } 31,36 \\
\text { Others: } 03,37,56\end{array}$ & Student's personals \\
\hline Empathy & $\begin{array}{l}\text { Teacher: } 22,33,35,42 \\
\text { Student Personnel: 51, } \\
\text { 52, } 53 \\
\text { Service: } 32,34,43,45\end{array}$ & $\begin{array}{c}\text { Teacher, Student } \\
\text { Personnel and Service } \\
\text { Delivery }\end{array}$ \\
\hline
\end{tabular}

Table 4: The dimensions of SERVQUAL used.

pant thought was most important and even left the option of adding unmentioned items.

Servqual information collection occurred in May 2019 and the focus group analysis occurred in July 2019. After collection, the data were treated and the students started the final exams of the school semester. Then the viability of the second stage was only possible after the closing of the activities. Table 5 presents the stages of data collection and analysis.

The choice of classes was based on specific classes of the course, composed only of students of the course, in which teachers were available to give in around 40 minutes for their realization.

Both in the application of SERVQUAL and in the use of the tools of the focus group, there was no interference from the investigator, 


\begin{tabular}{|c|c|c|c|}
\hline Stage & Procedure & Sample & Guidelines \\
\hline $\begin{array}{c}\text { SERVQUAL } \\
\text { Held in May } 2019 \\
\text { Objective: to analyze } \\
\text { the SERVQUAL tool and } \\
\text { the perception of stu- } \\
\text { dents in the academic } \\
\text { universe }\end{array}$ & $\begin{array}{l}\text { - } 3 \text { face-to-face classes of Production } \\
\text { Engineering (In two of them, one first } \\
\text { wondered about the expectation, then } \\
\text { about the reality. In another, the analy- } \\
\text { sis was inversion, to see if there was } \\
\text { divergence of the data.) } \\
\text { - Students in a face-to-face environ- } \\
\text { ment, with face-to-face explanation, but } \\
\text { the questionnaire available in digital } \\
\text { format (answers by mobile phones) }\end{array}$ & $\begin{array}{c}\text { - Only the volunteer students answered } \\
\text { - Total universe } 450 \text { student } \\
\text { - Sample of } 69 \text { Students, (15\% of the } \\
\text { universe) } \\
\text { Profile of students: } \\
\text { - From half to end of course } \\
\text { - Age group between } 18 \text { and } 49 \text { years, } \\
\text { but the predominance of } 18 \text { to } 30 \text { years } \\
\text { - Men and Women }\end{array}$ & $\begin{array}{c}\text { Explanation of: } \\
\text { - Research objective } \\
\text { - Operation (the difference } \\
\text { between expectation and } \\
\text { reality was highlighted) } \\
\text { Attention was requested } \\
\text { when answering }\end{array}$ \\
\hline $\begin{array}{l}\text { Data processing } \\
\text { June } 2019 \\
\text { Objective: obtaining } \\
\text { servqual results }\end{array}$ & $\begin{array}{l}\text { - Analysis via Excel, with the database } \\
\text { of the research performed. } \\
\text { - Difference in perceived quality with } \\
\text { all results together and also a separate } \\
\text { analysis by applied discipline (D1, D2, } \\
\text { D3) }\end{array}$ & $\begin{array}{c}\text { - Data analysis occurred through the } \\
\text { difference between 'Perceived Quality' } \\
\text { and 'Real Quality' } \\
\text { - For the preparation of the tables was } \\
\text { analyzed by size of SERVQUAL, } \\
\text { - The five points that had the most } \\
\text { evidence were analyzed, both in the } \\
\text { positive and negative perspectives. } \\
\text { - A table was elaborated that presents } \\
\text { the ranking of the first and last five by } \\
\text { application discipline (D1, D2 and D3), } \\
\text { seeking to analyze if there is a differ- } \\
\text { ence in the results obtained } \\
\text { - The written answers were analyzed } \\
\text { one by one, both from the perspec- } \\
\text { tive of what they scored, as well as } \\
\text { the terms they spoke. With this, it was } \\
\text { elaborated: } \\
\text { - A chart with the most important } \\
\text { topics } \\
\text { - A cloud of words, with the terms they } \\
\text { commented the most (It stands out } \\
\text { that for the word cloud were correlated } \\
\text { synonyms, errors of Portuguese typing) } \\
\text { and discarded prepositions and verbs } \\
\text { that did not add to the analysis. }\end{array}$ & $\begin{array}{l}\text { - Positive results: implies sat- } \\
\text { isfactory perception, that is, } \\
\text { that the perception of quality } \\
\text { exceeds the expected. } \\
\text {-Negative results: unsatisfac- } \\
\text { tory perception. } \\
\text { Cronbach's alpha was } \\
\text { analyzed, seeking a minimum } \\
\text { alpha of reliability of } 0.7, \\
\text { Data based on literary guide- } \\
\text { lines }[22,23]\end{array}$ \\
\hline $\begin{array}{c}\text { Focal Group } \\
\text { Held in July } 2019 \\
\text { Objective: validate SER- } \\
\text { VQUAL responses and } \\
\text { use complementary te- } \\
\text { chniques to understand } \\
\text { the data and method }\end{array}$ & $\begin{array}{l}\text { - Choice of experienced students } \\
\text { - Voluntary participation } \\
\text { - Face-to-face participation in the class- } \\
\text { room during the holidays } \\
\text { we sought to find the root cause of the } \\
\text { problems, through the five reasons or } \\
\text { the cause and effect diagram. } \\
\text { - This whole stage was physical (face- } \\
\text {-to-face and using pen and paper) }\end{array}$ & $\begin{array}{l}\text { - } 5 \text { experienced students (in the last } \\
\text { period of the course) }\end{array}$ & $\begin{array}{c}\text { Explanation of: } \\
\text { - Research objective } \\
\text { - The basic pillars for the } \\
\text { increase of items (Figure 2) } \\
\text { - The SERVQUAL model } \\
\text { - Search results } \\
\text { - The tools (Cause and Effect } \\
\text { Diagram, } 5 \text { whys and Interre- } \\
\text { lationship Diagram) } \\
\text { It was provided: } \\
\text { - Tutorials on how to use the } \\
\text { tools } \\
\text { - Blank sheets } \\
\text { - Sheets with outline of the } 3 \\
\text { tools } \\
\text { - Base pillars (Figure 2) }\end{array}$ \\
\hline $\begin{array}{c}\text { Data processing } \\
\text { 2nd half of } 2019 \\
\text { Objective: data closure }\end{array}$ & $\begin{array}{l}\text { - Pass the physical material to the vir- } \\
\text { tual and close the analyses } \\
\text { - Software used > Excel and PowerPoint }\end{array}$ & $\begin{array}{l}\text { The material made by the students } \\
\text { in the focus group was passed to the } \\
\text { computer }\end{array}$ & $\begin{array}{l}\text { In case of doubt the students } \\
\text { of the focus group were con- } \\
\text { tacted in the whatsapp group } \\
\text { created for the experiment. }\end{array}$ \\
\hline
\end{tabular}

Table 5: Methodological steps. 
unless to remove some punctual doubt. At the end of the application of the focus group tools, some questions were asked to better understand and validate the data.

About the application in the three classes, each class was named As D1, D2 and D3, namely?

- D1: Composed of 36 students. It was the most detailed explanation, following the normal order of the application and had the researcher present throughout the application;

- D2: Composed of 15 students. It was presented in an inverted way of the other. The researcher gave the lead and left the class responding to the experiment;

- D3: Composed of 18 students. The researcher gave the guide and then left the teacher of the discipline with the students responding, with application in the normal model.

The focus group was composed of five end-of-course students, considered as experienced, and their profile was:

- $\quad$ Male student, with more maturity, holds a management position in the market, coming from the transfer of another course of a state HEI;

- $\quad$ Male student, within the average age group of course training, coming from transfer of a federal HEI, of the same course. He has an internship in the area of the course, but in the administrative sector;

- Female student, within the average age group of the course, chose to study in a private HEI, even though she was able to go to a public one;

- $\quad$ Female student, slightly younger than the average course education, intern in the area of activity of the course;

- Female student, within the average age group of course training, interned in several areas throughout the course and engaged in institutional actions.

The results were presented by servqual dimension.

\section{Results and Discussion}

The dimension of 'Tangibility' aims to analyze whether the physical or tangible part is in accordance with the student's perception of quality. Table 6 shows in the Perceived Quality (QP) column that only 2 variables were positive (marked in black). This implies that the 'employee being well dressed' and the 'environment is decorated' have a higher quality perception than expected. However, all other categories were negative, demonstrating that the physical and tangible part of the HEI falls short of what was expected. ANIPO.

\begin{tabular}{|c|c|c|c|c|}
\hline & $\mathbf{N}$ & Questions asked & QP & $\begin{array}{c}\text { Items from } \\
\text { an HEI }\end{array}$ \\
\hline \multirow[t]{15}{*}{$\begin{array}{l}\text { Tangibi- } \\
\text { lidade }\end{array}$} & 1 & $\begin{array}{c}\text { Physical facilities are } \\
\text { visually appealing/ } \\
\text { beautiful }\end{array}$ & $-0,501$ & Infrastructure \\
\hline & 2 & $\begin{array}{l}\text { General campus facili- } \\
\text { ties be comfortable }\end{array}$ & $-0,733$ & Infrastructure \\
\hline & 4 & $\begin{array}{l}\text { The appearance of the } \\
\text { HEI to be consistent } \\
\text { with what it promises } \\
\text { to be }\end{array}$ & $-0,587$ & Infrastructure \\
\hline & 5 & $\begin{array}{l}\text { Laboratory equip- } \\
\text { ment is modern }\end{array}$ & $-0,793$ & Infrastructure \\
\hline & 6 & $\begin{array}{l}\text { The library have } \\
\text { updated books }\end{array}$ & $-0,707$ & Infrastructure \\
\hline & 7 & $\begin{array}{c}\text { The library have } \\
\text { enough books }\end{array}$ & $-1,206$ & Infrastructure \\
\hline & 8 & $\begin{array}{c}\text { The library have } \\
\text { diversity }\end{array}$ & $-0,745$ & Infrastructure \\
\hline & 9 & $\begin{array}{c}\text { Employees are well } \\
\text { dressed/tidy }\end{array}$ & 0,266 & Service \\
\hline & 10 & $\begin{array}{c}\text { The classrooms are } \\
\text { comfortable and at- } \\
\text { tractive }\end{array}$ & $-0,803$ & Infrastructure \\
\hline & 11 & $\begin{array}{l}\text { Lesson equipment is } \\
\text { modern and efficient }\end{array}$ & $-0,888$ & Infrastructure \\
\hline & 65 & $\begin{array}{c}\text { It has a clean environ- } \\
\text { ment }\end{array}$ & $-0,564$ & Infrastructure \\
\hline & 66 & $\begin{array}{c}\text { It has a comfortable } \\
\text { atmosphere }\end{array}$ & $-0,878$ & Infrastructure \\
\hline & 67 & $\begin{array}{l}\text { It has a decorated } \\
\text { atmosphere }\end{array}$ & 0,446 & Infrastructure \\
\hline & 68 & It has parking & $-1,321$ & Infrastructure \\
\hline & 69 & It has leisure facilities & $-0,885$ & Infrastructure \\
\hline
\end{tabular}

Table 6: Tangibility Dimension. 
The 'Reliability' dimension aims to see if what has been promised is delivered. Table 7 shows that the students' perception is negative, that is, the perceived quality is the non-fulfillment of expectations regarding the delivery of what was promised.

\begin{tabular}{|c|c|c|c|c|}
\hline & $\mathbf{N}$ & Questions asked & $\mathbf{Q P}$ & $\begin{array}{c}\text { Items } \\
\text { from an } \\
\text { HEI }\end{array}$ \\
\hline \multirow[t]{17}{*}{ Reliability } & 12 & $\begin{array}{l}\text { The Institution meet the } \\
\text { promised schedule }\end{array}$ & $-0,486$ & Academic \\
\hline & 13 & $\begin{array}{l}\text { Teachers meet the pre- } \\
\text { established schedule for } \\
\text { classes }\end{array}$ & $-0,262$ & Teacher \\
\hline & 15 & $\begin{array}{c}\text { There is quality in teach- } \\
\text { ing }\end{array}$ & $-0,585$ & Academic \\
\hline & 16 & $\begin{array}{l}\text { Academic experiences } \\
\text { aggregate in the course }\end{array}$ & $-0,636$ & Academic \\
\hline & 17 & $\begin{array}{l}\text { The content of the up- } \\
\text { dated disciplines }\end{array}$ & $-0,560$ & Academic \\
\hline & 19 & $\begin{array}{l}\text { Teachers have knowl- } \\
\text { edge }\end{array}$ & $-0,472$ & Teacher \\
\hline & 20 & $\begin{array}{l}\text { Teachers have practical } \\
\text { mastery of knowledge }\end{array}$ & $-0,387$ & Teacher \\
\hline & 21 & $\begin{array}{l}\text { Teachers have productiv- } \\
\text { ity of academic research }\end{array}$ & $-0,541$ & Teacher \\
\hline & 24 & $\begin{array}{l}\text { Meet the deadlines set in } \\
\text { the academic part }\end{array}$ & $-0,599$ & Academic \\
\hline & 25 & $\begin{array}{l}\text { Meet the deadlines set in } \\
\text { the administrative part }\end{array}$ & $-0,846$ & Service \\
\hline & 44 & $\begin{array}{c}\text { Class schedules are at } \\
\text { convenient times }\end{array}$ & $-0,432$ & Academic \\
\hline & 48 & Having social activities & $-0,328$ & - \\
\hline & 57 & $\begin{array}{l}\text { The methodology of } \\
\text { teachers being playful }\end{array}$ & $-0,577$ & Teacher \\
\hline & 58 & $\begin{array}{l}\text { The constant extracur- } \\
\text { ricular activities }\end{array}$ & $-0,612$ & Academic \\
\hline & 59 & Academic diversity & $-0,418$ & Academic \\
\hline & 62 & $\begin{array}{l}\text { Evaluation of the course } \\
\text { in mec }\end{array}$ & $-0,421$ & Academic \\
\hline & 63 & $\begin{array}{l}\text { Evaluation of THE HEI } \\
\text { in mec }\end{array}$ & $-0,378$ & Academic \\
\hline
\end{tabular}

Table 7: Reliability Dimension.

The dimension of 'service promptness' focuses on the analysis of care, with emphasis on the employee's approach. Table 8 shows that only the item 'of employees being too busy' is above expectations, again referring to the negative perspective, which generates dissatisfaction.

\begin{tabular}{|c|c|c|c|c|}
\hline & $\mathbf{N}$ & Questions asked & QP & $\begin{array}{c}\text { Items } \\
\text { from an } \\
\text { HEI }\end{array}$ \\
\hline \multirow[t]{12}{*}{$\begin{array}{l}\text { Promptness } \\
\text { of service }\end{array}$} & 14 & $\begin{array}{c}\text { THE IES have an inter- } \\
\text { est in solving student } \\
\text { problems }\end{array}$ & $-1,553$ & Service \\
\hline & 23 & $\begin{array}{l}\text { Quickly meet student } \\
\text { demands }\end{array}$ & $-1,376$ & Service \\
\hline & 26 & $\begin{array}{l}\text { Employees are always } \\
\text { willing to help }\end{array}$ & $-1,010$ & Service \\
\hline & 28 & $\begin{array}{l}\text { Employees have respon- } \\
\text { siveness (ability to re- } \\
\text { spond or indicate where } \\
\text { to find the answer) }\end{array}$ & $-1,171$ & Service \\
\hline & 29 & $\begin{array}{l}\text { Employees are always } \\
\text { too busy to serve the } \\
\text { customer }\end{array}$ & 0,704 & Service \\
\hline & 38 & $\begin{array}{l}\text { Employees be polite/ } \\
\text { kind }\end{array}$ & $-0,744$ & Service \\
\hline & 39 & Teachers be polite/kind & $-0,644$ & Teacher \\
\hline & 41 & $\begin{array}{c}\text { Employees know how to } \\
\text { answer questions }\end{array}$ & $-0,564$ & Service \\
\hline & 46 & $\begin{array}{l}\text { Life on campus extra } \\
\text { classroom }\end{array}$ & $-0,532$ & Service \\
\hline & 47 & Service standardization & $-0,698$ & Service \\
\hline & 61 & $\begin{array}{l}\text { Scholarships and fund- } \\
\text { ing for students }\end{array}$ & $-0,698$ & Service \\
\hline & 70 & Service standardization & $-0,622$ & Service \\
\hline
\end{tabular}

Table 8: Service Dimension Promptness.

The dimension of 'Intangibility' focuses on the analysis of what is immaterial, with more difficult measurement and more focused on subjectivity. Table 9 shows that only the 'teachers' curriculum' is higher than expected, all the other leave to be desired with regard to the perceived quality of the immaterial, both in the aspects of service, as well as of teachers and student staff. 


\begin{tabular}{|c|c|c|c|c|}
\hline & $\mathbf{N}$ & Questions asked & QP & $\begin{array}{c}\text { Items from } \\
\text { an HEI }\end{array}$ \\
\hline \multirow{13}{*}{$\begin{array}{l}\text { Intangi- } \\
\text { bility }\end{array}$} & 3 & Campus security & $-1,319$ & - \\
\hline & 18 & $\begin{array}{c}\text { The teachers' curriculum } \\
\text { is good }\end{array}$ & 0,305 & Teacher \\
\hline & 30 & Teachers be trusted & $-0,645$ & Teacher \\
\hline & 31 & Employees be trusted & $-0,658$ & Service \\
\hline & 36 & $\begin{array}{l}\text { IES' reputation in the } \\
\text { labour market }\end{array}$ & $-0,446$ & Service \\
\hline & 37 & $\begin{array}{l}\text { Feel safe (in the emo- } \\
\text { tional sense and not } \\
\text { safety-danger) with } \\
\text { employees }\end{array}$ & $-0,378$ & - \\
\hline & 49 & $\begin{array}{l}\text { The network with stu- } \\
\text { dents }\end{array}$ & $-0,892$ & $\begin{array}{l}\text { Student's } \\
\text { Personal }\end{array}$ \\
\hline & 50 & $\begin{array}{c}\text { The network with teach- } \\
\text { ers }\end{array}$ & $-0,867$ & Teacher \\
\hline & 54 & $\begin{array}{l}\text { The feeling of justice } \\
\text { inside the classroom }\end{array}$ & $-0,672$ & $\begin{array}{l}\text { Student's } \\
\text { Personal }\end{array}$ \\
\hline & 55 & $\begin{array}{l}\text { The effort that the stu- } \\
\text { dent makes to pass in the } \\
\text { disciplines }\end{array}$ & $-0,592$ & $\begin{array}{l}\text { Student's } \\
\text { Personal }\end{array}$ \\
\hline & 56 & The level of evaluation & $-0,571$ & - \\
\hline & 60 & $\begin{array}{c}\text { Students' commitment } \\
\text { to study }\end{array}$ & $-0,938$ & $\begin{array}{l}\text { Student's } \\
\text { Personal }\end{array}$ \\
\hline & 64 & $\begin{array}{l}\text { Environment for social } \\
\text { integration }\end{array}$ & $-0,434$ & $\begin{array}{l}\text { Student's } \\
\text { Personal }\end{array}$ \\
\hline
\end{tabular}

Table 9: Intangibility Dimension.

Finally, the dimension of 'Empathy' focuses on the analysis of attention and individualization with students. Table 10 shows that students expect more from empathy than they receive.

\begin{tabular}{|c|c|c|c|c|}
\hline & $\mathbf{N}$ & Questions asked & QP & $\begin{array}{c}\text { Items from } \\
\text { an HEI }\end{array}$ \\
\hline Empathy & 22 & $\begin{array}{c}\text { Teacher's concern for } \\
\text { the student }\end{array}$ & $-0,867$ & Teacher \\
\cline { 2 - 5 } & 32 & $\begin{array}{c}\text { Employees fully un- } \\
\text { derstand the student's } \\
\text { needs/feelings }\end{array}$ & $-0,924$ & Service \\
\cline { 2 - 5 } & 33 & $\begin{array}{c}\text { Teachers fully under- } \\
\text { stand the student's } \\
\text { needs/feelings }\end{array}$ & $-0,903$ & Teacher \\
\hline
\end{tabular}

\begin{tabular}{|c|c|c|c|c|}
\hline 34 & $\begin{array}{c}\text { The HEI give individual- } \\
\text { ized attention to each } \\
\text { student }\end{array}$ & $-0,687$ & Service \\
\hline 35 & $\begin{array}{c}\text { Teachers give individu- } \\
\text { alized attention to each } \\
\text { student }\end{array}$ & $-0,491$ & Teacher \\
\hline 42 & $\begin{array}{c}\text { Teachers embark to- } \\
\text { gether in the interests of } \\
\text { students }\end{array}$ & $-0,779$ & Teacher \\
\hline 43 & $\begin{array}{c}\text { Employees fully under- } \\
\text { stand customer needs/ } \\
\text { feelings }\end{array}$ & $-0,667$ & Service \\
\hline 45 & $\begin{array}{c}\text { THE IES is concerned } \\
\text { about the student's } \\
\text { opinion }\end{array}$ & $-1,325$ & Service \\
\hline 51 & $\begin{array}{c}\text { There is monitoring of } \\
\text { the employability needs } \\
\text { of students }\end{array}$ & $-1,115$ & $\begin{array}{c}\text { Student's } \\
\text { Personal }\end{array}$ \\
\hline 52 & $\begin{array}{c}\text { The feeling of belonging } \\
\text { given by IES }\end{array}$ & $-0,442$ & $\begin{array}{c}\text { Student's } \\
\text { Personal }\end{array}$ \\
\hline 53 & $\begin{array}{c}\text { The emotional support } \\
\text { Personal }\end{array}$ & $-0,665$ & Student's \\
\hline
\end{tabular}

Table 10: Empathy Dimension.

The five items that most impacted the perceived quality from a positive and negative perspective are presented in table 11, however in the positive QP they only had 4 items.

\begin{tabular}{|c|c|c|c|}
\hline $\mathbf{N}$ & Dimension & Item analyzed & QP \\
\hline 9 & Tangibilidade & Employees are well dressed/tidy & $+0,27$ \\
\hline 18 & Intangibility & The teachers' curriculum is good & $+0,31$ \\
\hline 29 & $\begin{array}{c}\text { Service } \\
\text { Promptness }\end{array}$ & $\begin{array}{c}\text { Employees are always too busy to } \\
\text { serve the customer }\end{array}$ & $+0,70$ \\
\hline 67 & Tangibilidade & It has a decorated atmosphere & $+0,45$ \\
\hline 3 & Intangibility & Campus security & $-1,32$ \\
\hline 14 & $\begin{array}{c}\text { Service } \\
\text { Promptness }\end{array}$ & $\begin{array}{c}\text { THE IES have an interest in solv- } \\
\text { ing student problems }\end{array}$ & $-1,55$ \\
\hline 23 & $\begin{array}{c}\text { Service } \\
\text { Promptness }\end{array}$ & $\begin{array}{c}\text { Quickly meet student demands } \\
\text { Them IES is concerned about the } \\
\text { student's opinion }\end{array}$ & $-1,38$ \\
\hline 45 & Empathy & $\begin{array}{c}\text { THE } \\
\text { It has parking }\end{array}$ & $-1,32$ \\
\hline 68 & Tangibilidade & &
\end{tabular}

Table 11: Sectors and areas with higher index. 
By dividing the analysis by each of the 3 classes, table 12 in relation to the division of the groups, there was a variation between the items highlighted. Items with a green background are part of the most positive items, and items with a red background are part of the five most positive items. It is evident that there was a subtle divergence between the groups, especially in the $\mathrm{d} 2$ group, which had the questionnaire applied in an inverted way. Group D1, on the other hand, converged more with the final answers, as there was also more number of students who answered.

\begin{tabular}{|c|c|c|c|c|c|c|}
\hline $\mathrm{N}$ & Dimension & Item analyzed & D1 & D2 & D3 & Gen- \\
\hline 3 & Intangibil- & Campus security & $-1,49$ & $-0,75$ & $-1,12$ & $-1,32$ \\
\hline & & & & & & \\
\hline 7 & Tangibili- & The library have & $-1,09$ & $-1,06$ & $-1,42$ & $-1,21$ \\
\hline 8 & $\begin{array}{l}\text { Tangibili- } \\
\text { dade }\end{array}$ & $\begin{array}{c}\text { The library have } \\
\text { diversity }\end{array}$ & $-0,78$ & $-0,27$ & $-1,00$ & $-0,75$ \\
\hline 9 & $\begin{array}{l}\text { Tangibili- } \\
\text { dade }\end{array}$ & $\begin{array}{c}\text { Employees are } \\
\text { well dressed/tidy }\end{array}$ & 0,63 & 0,11 & $-0,39$ & 0,27 \\
\hline 12 & Reliability & $\begin{array}{c}\text { The Institution } \\
\text { meet the promised } \\
\text { schedule }\end{array}$ & $-0,48$ & 0,08 & $-0,77$ & $-0,49$ \\
\hline 14 & $\begin{array}{l}\text { Promptness } \\
\text { of service }\end{array}$ & $\begin{array}{l}\text { THE IES have an } \\
\text { interest in solving } \\
\text { student problems }\end{array}$ & $-2,05$ & $-1,06$ & $-1,15$ & $-1,55$ \\
\hline 18 & \begin{tabular}{|c|}
$\begin{array}{c}\text { Intangibil- } \\
\text { ity }\end{array}$ \\
\end{tabular} & $\begin{array}{l}\text { The teachers' cur- } \\
\text { riculum is good }\end{array}$ & 0,61 & 0,33 & $-0,08$ & 0,31 \\
\hline 23 & $\begin{array}{c}\text { Promptness } \\
\text { of service }\end{array}$ & $\begin{array}{c}\text { Quickly meet stu- } \\
\text { dent demands }\end{array}$ & $-1,84$ & $-1,38$ & $-0,92$ & $-1,38$ \\
\hline 26 & $\begin{array}{l}\text { Promptness } \\
\text { of service }\end{array}$ & $\begin{array}{c}\text { Employees are } \\
\text { always willing to } \\
\text { help }\end{array}$ & $-1,24$ & $-1,38$ & $-0,62$ & $-1,01$ \\
\hline 28 & $\begin{array}{c}\text { Promptness } \\
\text { of service }\end{array}$ & $\begin{array}{l}\text { Employees have } \\
\text { Responsiveness } \\
\text { (ability to respond } \\
\text { or indicate where } \\
\text { to find the answer) }\end{array}$ & $-1,33$ & $-1,00$ & $-1,00$ & $-1,17$ \\
\hline 29 & $\begin{array}{c}\text { Promptness } \\
\text { of service }\end{array}$ & $\begin{array}{l}\text { Employees are } \\
\text { always too busy to } \\
\text { serve the customer }\end{array}$ & 0,99 & $-0,33$ & 0,77 & 0,70 \\
\hline 32 & Empathy & $\begin{array}{l}\text { Employees fully } \\
\text { understand the } \\
\text { student's needs/ } \\
\text { feelings }\end{array}$ & $-1,29$ & $-1,40$ & $-0,42$ & $-0,92$ \\
\hline
\end{tabular}

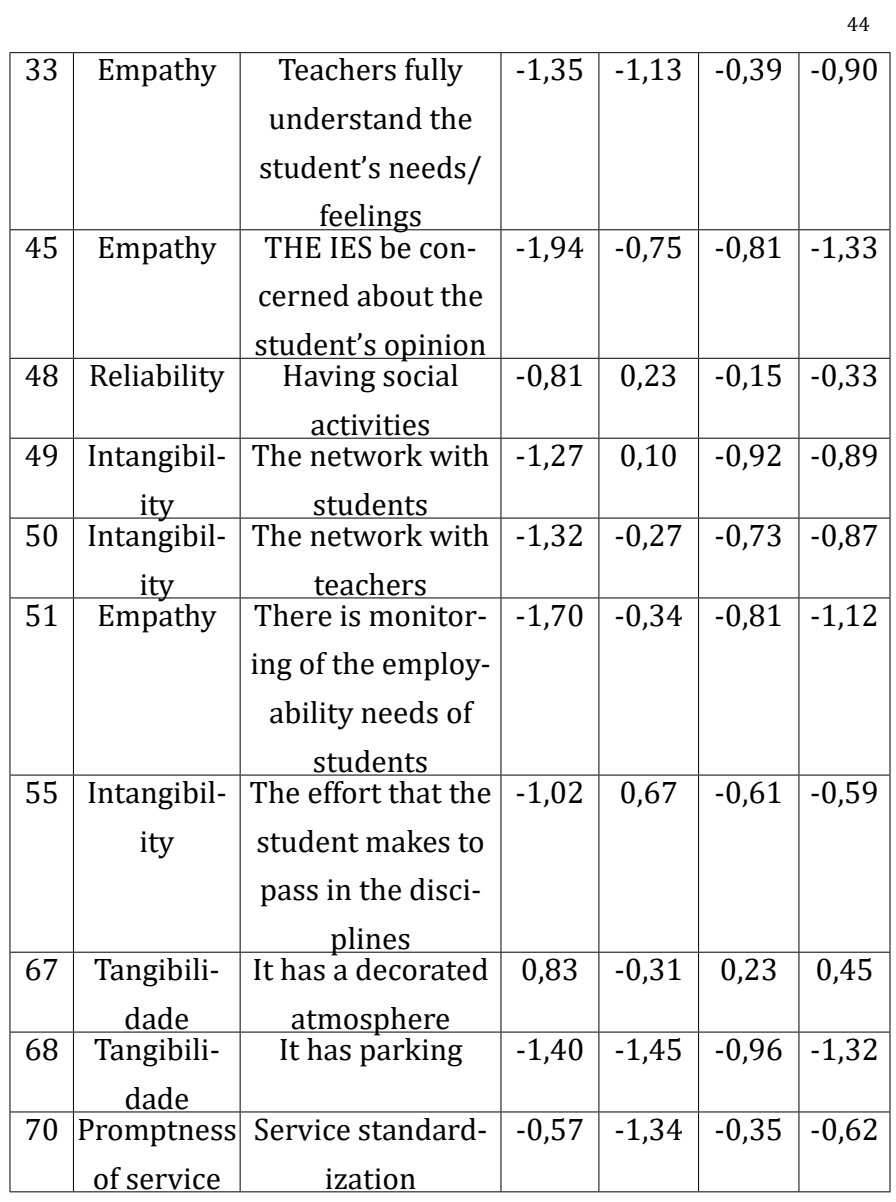

Table 12: Most commented sectors and areas per class.

Cronbach's Alpha coefficient (shown in Table 13) in all perspectives had a value higher than 0.7. In fact, a very high value (above 0.9 ), which means that there is redundancy in the questions and redundant items should be eliminated. This makes sense, since it has similar points such as item 31 ('employees be reliable) and item 30 'teachers be reliable', since teachers are also employees of the institution.

\begin{tabular}{|c|c|c|}
\hline \multirow{2}{*}{} & \multicolumn{2}{|c|}{ Alfa de Cronbach } \\
\cline { 2 - 3 } & Ideal & Real \\
\hline D1 & 0,918 & 0,975 \\
\hline D2 & 0,990 & 0,987 \\
\hline D3 & 0,964 & 0,987 \\
\hline General & 0,958 & 0,983 \\
\hline
\end{tabular}

Table 13: Cronbach's Alpha. 
In open questions, 'teaching', with emphasis on 'teaching quality', was the one that was most commented, followed by 'empathy' and 'employability'. However, if all approaches related to 'teacher' ('training', 'student relationship', 'knowledge', 'reliability' were combined, the 'teacher' would be in second place. Figure 3 shows the degree of repetition of each item. The first term, 'everything' converges with the answer 'everything is important' or similar.

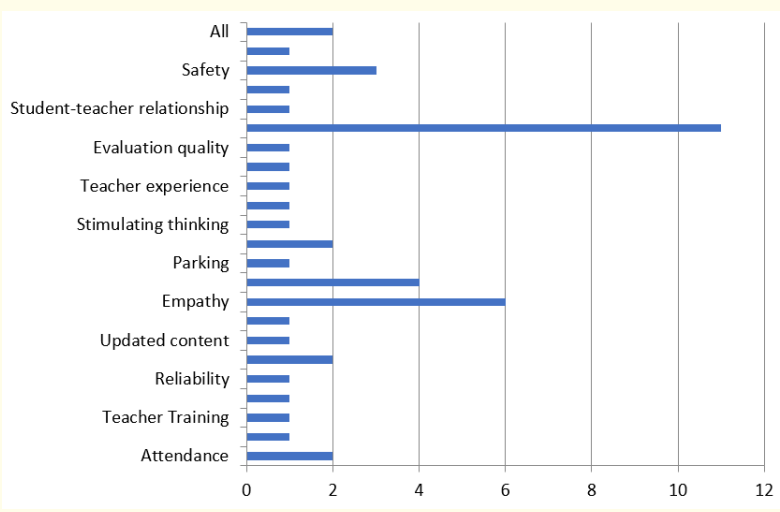

Figure 3: Graph of the most commented terms of the open question.

Even with the questionnaire not presenting the pillars of SERVQUAL, one student highlighted 'Empathy', with the following comment: "Empathy of the IES towards the student and that this is applied in the classroom. Because many students are suffering from mental illnessdeveloped at the university. So, the feeling of putting oneself in the student's place would make total difference by bringing greater benefits such as a domino effect, such as feeling of belonging, better care, problem solving, playful didactics (because if the subject is already difficult we will try to see another way of teaching) among others" (Q28).

Figure 4 presents the word cloud that addresses the content of all open comments. It is possible to see that the term 'student' came first, followed by 'teaching', 'teacher' and 'quality'.

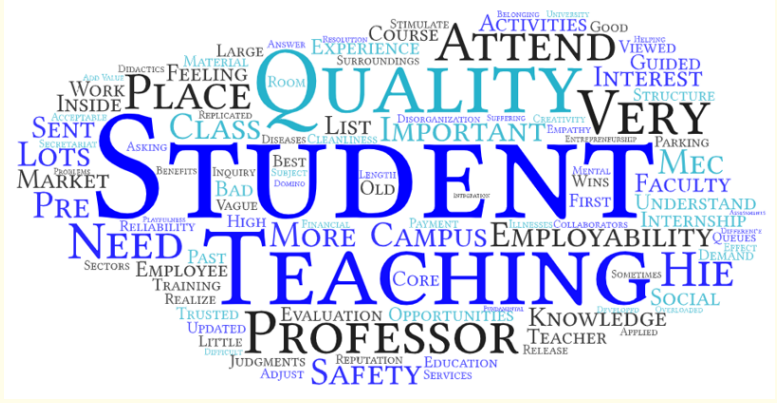

Figure 4: Open Question Word Cloud.
In the focus group, the students analyzed the results and pillars, resulting in the creation of the interrelationship diagram through the five pillars of Figure 2 (teacher, service provision, infrastructure, student and academic personnel) and creating the relationship between them. The result found is shown in figure 5, where in the analysis the students missed the sixth pillar, which would be the 'institutional management'. It is important to highlight that, for them, all 6 pillars have connection, but the main links were highlighted.

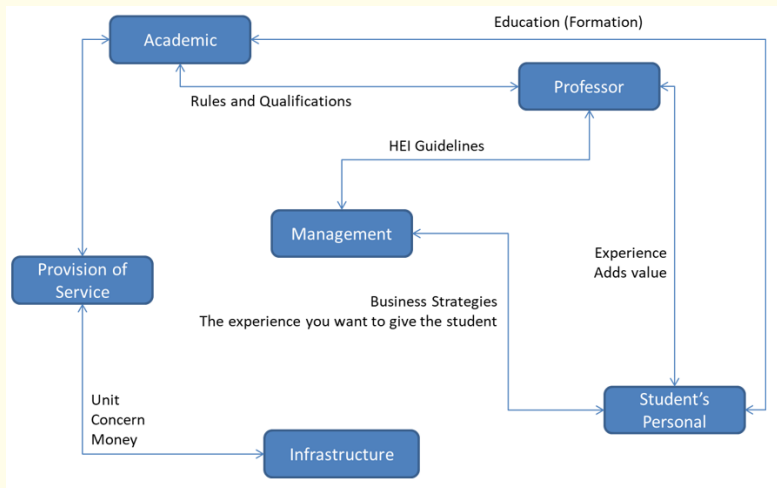

Figure 5: Industry interrelationship diagram "problem".

Students chose a problem they felt was the primary to use in the Cause and Effect tool (Ishikawa). The problem chosen unanimously was 'service of the financial sector and the secretariat', which converged to the worst evaluations (items 14 and 23) and to some open comments. However, the students realized that they did not have all the information necessary to fill out the entire diagram, but from their perspective the main point for the cause of the problem was the 'method', the 'people' and the 'machine', respectively. The result is shown in figure 6.

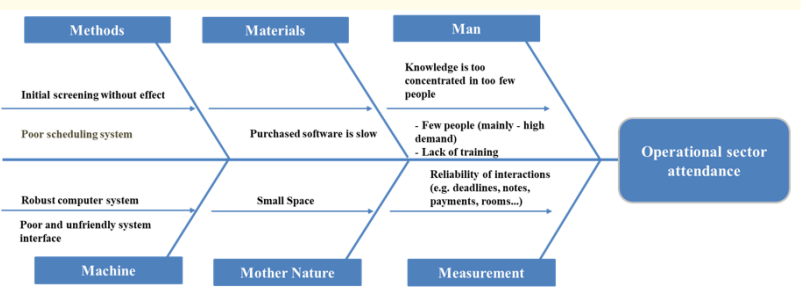

Figure 6: Cause and effect diagram.

It was also questioned why $95 \%$ of the items analyzed are below the students' expectations, and one student stated: "people classify their vision", "you should not look at isolated things, this is all a set", trying to justify the negative bias of the results. 
The group's conclusion is that these more negative factors of SERVQUAL interfere with direct student satisfaction, may not be the main problem, but perhaps what causes the most 'stress' for them.

On the positive aspects students believe there are more things that are not on the list. One student mentioned that the 'recognition of the market', the 'quality of teachers', the 'attendance in coordination' were points that exceeded expectation and would be in front of item 9 (appearance of employees) and 67 (decoration).

In a moment of reflection of the result a student mentioned: "it will be that the people are even connected in the packaging to the institution", referring to superficial and momentary aspects. As a final observation, there is the following comment: "I believe that people end up saying the feelings that bother the most, in what bother the most times".

\section{Conclusion}

The SERVQUAL model used the base pillars, but a correlation was made with the distribution of academic pillars, which resulted predominantly in:

- Tangibility Infrastructure $\rightarrow$

- $\quad$ Academic and faculty reliability $\rightarrow$

- $\quad$ Provision of service Provision of Service $\rightarrow$

- $\quad$ Student Personal Intangibility $\rightarrow$

- $\quad$ Empathy People $\rightarrow$

The methodology used 70 items of analysis concatenating several points studied in the literature, or in previous studies. The result, already expected, was a high alpha from Cronbach. This means consistency in what was questioned, but at the same time redundancy of items which generates the need to reduce the quantity. This information was already expected, because in the preparation of the material itself, it was noticed the overlap of factors, such as teachers with collaborators or more technical issues such as the course grade or the institution's grade. Neverthemore, it was desired to study to see if there was divergence in the students' perception.

Regarding the results of SERVQUAL, it was possible to perceive that the quality perceived in all 5 dimensions is below, that is, the students expect more than the institution offer. This negative perception of the service offer generates an opportunity for the institution to be able to work in front of the main items evaluated.

The points that do not directly interfere in education, such as operational service and 'parking', in the end, were points that directly impact their perception of quality and satisfaction. This result makes the investigation of academic sectors challenging, as well as the measurement of subjectivity, since academic excellence alone is not sufficient for positive perception.

The validation of the SERVQUAL result with the focus group generated the convergence of the consistency of the results, guideing the responses under what the students feel, from the perspective of what "bothers" or "generates stress". It was also diagnosed that the result gives room for doubt of what students are evaluating, since these 'feelings' can camouflage opposite or more important items, generating difficulty in understanding what really is the root cause of the problem and what impacts satisfaction. In addition to the need to add the sixth pillar of institutional management.

We saw the validity of using the focus group to validate the answers and understand the perception behind the answers and for this a group formed by expert users.

SERVQUAL was able to detect the problems that really "annoy" the students, reinforced by the focus group as "very first place", demonstrating to be a good tool of analysis in this perspective.

The inversion of the application was interesting, since the students of the inverted method had a slightly better tendency towards the positive perspective. It was then possible to perceive that the context and stimuli interfere in the interviewees' response, since the alternation of reflection (thinking about what has and then the ideal) resulted in a less negative result, although it still contains a perceived negative quality.

In the word cloud generated by the comments, it was possible to see that "student" came first, followed by "teaching" and "quality". This endorses the thinking of the focus group, in which the needs of students must be understood.

The main problems presented by SERVQUAL converged on what students see as a problem, but the positives diverged, which leads to the limitation mentioned by Swait and Adarnowicz [36] 
and Weathers., et al. [37] of this type of experiment, because it allows the interviewees to have a predisposition to an answer, which, in this case, was negative.

Finally, it is concluded that SERVQUAL is a good analysis tool for detecting problems that bother users, that the analysis of respondents is under an overview, of the service set, and not under isolated points. Thus, the method understands the quality perceived-felt by the students, channeling mainly to their frustrations or disappointments.

The future is suggested a reduction of items to have a more attractive number, as well as a simpler way to work with the focus group - which requires less time.

\section{Bibliography}

1. Meyer C and Schwager A. "Understanding customer experience". Harvard Business Review 85.2 (2007): 117-126.

2. Wm Almeida. "On the end of the gratuity of Brazilian public higher education". Research Notebooks 49.173 (2019): 10-27.

3. Census dand Higher Education. "Statistical notes 2019". Ministry of Education.

4. ANDIFES. "V National Survey of Socioeconomic and Cultural Profile of UNDERGRADUATE STUDENTS OF IFES - 2018". Fonoprace (2018): 316.

5. Aronowitz S and Giroux HA. "The corporate university and the politics of education". The Educational Forum 64 (2008): 332339.

6. File CHP., et al. "Social roles in higher education: Studentclient, Teacher-manager-educator, institution of commercial education". Science Administration 8.15 (2006): 2-27.

7. Fonseca V. "Importance of emotions in learning: a neuropsychopedagogical approach". Psychopedagogy Magazine 33.102 (2016): 365-384.

8. Slater SF and Narver JC. "Market orientation and the learning organization". Journal of Marketing 59.3 (1995): 63-74.

9. Mark E. "Student satisfaction and the costumer focus in higher education". Journal of Higher Education Policy Management 35.1 (2013): 2-10.

10. Kureemun B and Fantina R. 'Your customers' perception of quality: What it means to your bottom line and how to control it". CRC Press Taylor and Francis Group (2011).
11. Parasuraman A., et al. "SERVQUAL: A Multiple-Item Scale For Measuring Customer Perceptions of Service Quality". Journal of Retailing 64.1 (1988): 12-40.

12. IM brook. "Mapping hedonomy and emotional experiences: The perception of the student in higher education from the perspective of emotional design". Federal University of Pernambuco (Doctorate inDesign) (2020): 472.

13. Ribeiro IM., et al. "Academic sectors that interfere with student satisfaction in higher education". Acta Scientarium Education (2021): 1-28.

14. Thomas EH and Galambos N. "What satisfies students? Mining student-opinion data with regression and decision tree analysis". Research in Higher Education 45.3 (2004): 251-267.

15. Peng PJ and Samah AJA. "Measuring student's satisfaction for quality education in a e-learning university". Unitar e-Journal 2.1 (2006): 11-21.

16. Gibson A. "Measuring business students satisfaction: a review and summary of the major predictors". Journal of Higher Education Policy and Management 32.3 (2010): 251-259.

17. Parasuraman A., et al. "A conceptual model of service quality and its implications for future research". Journal of Marketing 49.4 (1985): 41-50.

18. Leblanc G and Nguyen N. "Searching for excellence in business education: An exploratory study of customer impressions of service quality". International Journal of Educational Management 11.2 (1997): 72-79.

19. Douglas D., et al. "Measuring student satisfaction at a UK university". Quality Assurance in Education 14.3 (2006): 251-267.

20. Bearden WO., et al. "Handbook of Marketing Scales: Multi-item measures for marketing and consumer behavior research". Sage (2011).

21. Lourenço CDS and Knop MFT. "Higher education in administration and perception of the quality of services: An application of the SERVQUAL scale". Brazilian Business Management Magazine 13.39 (2011): 219-233.

22. Stefano NM., et al. "A fuzzy SERVQUAL based method for ecaluated of servisse quality in the hotel industry". Procedia CIRP 30 (2015): 433-438.

23. Hair E and Chirinos JL. "Validation and applicability of modified SERVQUAL surveys to measure the satisfaction of external users in health services". Heredian Medica Magazine 23.2 (2012): 89-95. 
24. Hasan HFA., et al. "Service Quality and Student Satisfaction: A Case Study at Private Higher Education Institutions". International Business Research 1.3 (2008): 163-175.

25. Bigné E., et al. "Perceived quality and satisfaction in multiservice organizations: the case of Spanish public service". Journal of Services Marketing 17.4 (2003): 420-442.

26. Ademir C and Gülcan, Y. "Student satisfaction in higher education: A Turkish case. Higher Education". Management and Policy 16.2 (2004): 109-122.

27. Rastoder A., et al. "Perceptions of Students towards Quality of Services at Private Higher Education Institution in Bosnia and Herzegovina". European Researcher Series A 101.12 (2015): 783-790.

28. Sohail MS and Shaikh NM. "Quest for excellence in business education: A study of student impressions of service quality". International Journal of Education Management 18.1 (2004): 58-65.

29. Buttle F. "SERVQUAL: review, critique, research agenda”. European Journal of Marketing 30.1 (1996): 8-32.

30. Asubonteng P., et al. "SERVQUAL revisited: a critical review of service quality". The Journal of Services Marketing 10.6 (1996): 61-81.

31. Pariseau SE and Mcdaniel JR. "Assessing service quality in business schools". International Journal of Quality and Reliability Management 14.3 (1997): 204-218.

32. Galloway, L. "Quality perceptions of internal and external customers: a case study in educational administration". The TQM Magazine 10.1 (1998): 20-26.

33. MV Rodrigues. "Actions for quality: strategic and integrated management for the improvement of processes in the pursuit of quality and competitiveness". Elsevier (2014).

34. Bergman B and Klefsjö B. "Quality from Customer Needs to Customer Satisfaction”. Studentlitteratur AB (2010).

35. Swartz TA and Brown SW. "Consumer and provider expectations and experiences in evaluating professional service quality". Journal of the Academy of Marketing Science 17.2 (1989): 189-195.

36. Swait JS and Adamowicz W. "The influence of task complexity on consumer choice: a latent class model of decision strategy". Journal of Consumer Research 21.1 (2001): 189-199.
37. Weathers D., et al. "The impact of the number of scale points, dispositional factors, and the status quo heuristic on scale reliability and response accuracy". Journal of Business Research 58.11 (2005): 1516-1524.

\section{Volume 5 Issue 6 June 2021 \\ (C) All rights are reserved by Iara Margolis and Bernar- do Providência.}

